\title{
Mieć czy być w ruchu - IV Światowy Kongres Mobilności Współdzielonej
}

\section{Maciej Sulmicki}

Modele mobilności i sposobów przemieszczania się ulegają zmianom wraz z rozwojem technologicznym i powstawaniem nowych rozwiązań w zakresie organizacji transportu. Na mobilność wpływają też takie czynniki jak stosunek do posiadania środków transportu, czy sposoby wykonywania i organizacji pracy, m.in., poprzez rozwój platform pośredniczących między klientami a wykonawcami. Takie platformy wykorzystywane są również w usługach przewozowych i korzystania z pojazdów współdzielonych. Jesienią 2016 roku w Warszawie odbył się IV Światowy Kongres Mobilności Współdzielonej (World Collaborative Mobility Congress - WoCoMoCo), na którym dyskutowano nad aktualnymi trendami zmian w systemach transportowych i perspektywami na przyszłość.

\section{Wyzwania dla aglomeracji}

Na wstępie Jörg Beckmann, prezes szwajcarskiej Akademii Mobilności, zwrócił uwagę na widoczne trendy: szybki rozwój systemów roweru publicznego, jak też plany rozwoju pojazdów o napędzie elektrycznym - w tym samochodów publicznych. Wiceprezydent Warszawy, Michał Olszewski podkreślił wagę kwestii mobilności we współczesnych dużych miastach i otaczających je aglomeracjach, w tym w Obszarze Metropolitalnym Warszawy. Stwierdził, że Warszawa konsekwentne dąży do zwiększenia udziału transportu zbiorowego oraz ruchu rowerowego i pieszego - zarówno ze względu na potrzebę zapewnienia efektywnego systemu transportowego, jak i ograniczenia emisji szkodliwych dla zdrowia i środowiska zanieczyszczeń. Zaznaczył, że kluczowa jest przy tym zmiana nawyków mieszkańców. Sekretarz Generalny Światowego Stowarzyszenia Samochodowego (Federation Internationale de l'Automobile) zwrócił uwagę na stopniowe odchodzenie od poruszania się własnymi samochodami (zaznaczył, że sam przez większość czasu takowego nie posiadał) na rzecz bardziej elastycznych modeli mobilności. Wśród wyzwań podkreślił potrzebę integracji różnych wdrażanych rozwiązań, w tym w zakresie infrastruktury - twardej i miękkiej, jak też na etapie prac planistycznych.

W panelu dyskusyjnym Tamás Dombi z warszawskiego Zarządu Transportu Miejskiego podkreślił, że największym wyzwaniem w zakresie mobilności, przed którym stoją władze w Warszawie - jak też, szerzej, w Polsce - jest ograniczenie liczby samochodów i natężenia ruchu samochodowego. Stąd zachodzi potrzeba rozwoju m.in. mobilności współdzielonej, by unaocznić, że istnieją efektywne alternatywy dla poruszania się własnym samochodem i skłonić mieszkańców do korzystania z nich. Lewis Chen, założyciel Singapurskiego 
Stowarzyszenia Samochodów Współdzielonych (Carsharing Association of Singapore) zauważył, że konieczne jest ograniczenie postrzegania samochodu jako elementu stylu życia, aby ułatwić bardziej racjonalny dobór środków transportu. Michael Roschlau, wieloletni prezes Kanadyjskiego Stowarzyszenia Transportu Miejskiego, podkreślił potrzebę dokonania zdecydowanego wyboru przez władze publiczne, tak by wskazać podmiotom prywatnym kierunek zmian - na rzecz efektywnego systemu transportowego. W dyskusji zauważano też szansę ominięcia problematycznego etapu gwałtownego przyrostu liczby prywatnych samochodów w państwach rozwijających się, w przypadku przejścia od razu do mobilności współdzielonej.

\section{Przeskoczyć przyrost dróg w miastach}

Prezentację nt. mobilności współdzielonej w Azji przedstawił Lewis Chen. Zwrócił uwagę na potrzebę dostosowania działań do lokalnych warunków, jako przykład podając niepotrzebny rozwój dróg szybkiego ruchu w azjatyckich miastach, szybko rozwijających się, ale bardziej zwartych od amerykańskich. Rozwój motoryzacji indywidualnej grozi ogromnymi problemami komunikacyjnymi. Dlatego też w Chinach pojawia się wsparcie dla mobilności współdzielonej, by uniknąć wpadnięcia w pętlę rozbudowy infrastruktury drogowej i wzrostu liczby samochodów, skutkującą wzrostem wydatków bez faktycznej poprawy warunków ruchu i życia. Wzrost liczby samochodów stanowi też utrudnienie w rozwoju zrównoważonego systemu transportowego, który powinien uczynić zbędnym posiadanie samochodu i poruszanie się nim, oferując bardziej atrakcyjne alternatywy. Taki system może też przynosić zyski zamiast wymagać dotacji (jako przykład przedstawiono Hong Kong).

Wielowymiarowe podejście powinno przy tym wpływać zarówno na zachowania, jak i motywacje, z których wynikają. W tym celu należy przede wszystkim zachęcać do korzystania z komunikacji zbiorowej (samochody współdzielone mogą być jej uzupełnieniem, ale nie zastępować), stosować zintegrowane podejście do planowania rozwoju transportu i zagospodarowania przestrzennego, ograniczać potoki ruchu, zmniejszając zapotrzebowanie na podróże i dążyć do bardziej efektywnego wykorzystania infrastruktury i pojazdów (bez zwiększania ich liczby, z przesunięciem nacisku z posiadania na korzystanie). Technologia powinna służyć do zapewnienia bardziej atrakcyjnej i łatwiejszej podróży efektywnymi środkami transportu, jak też na bieżąco dostosowywać się do potrzeb podróżnych.

W przypadku Singapuru, również taksówki są elementem systemu transportu publicznego. Aktualnym celem Singapuru jest zwiększenie udziału podróży w godzinach szczytu wykonywanych transportem zbiorowym z 63\% (2013) do 75\% (2030). Równocześnie odsetek gospodarstw domowych w zasięgu 10-minutowego spaceru do stacji kolejowej ma wzrosnąć do 80\%, a długość sieci dróg rowerowych - z 213 do 700 km. Takie działania powinny umożliwić bardziej efektywne wykorzystanie przestrzeni, obecnie w dużej mierze zajętej przez infrastrukturę samochodową.

Jednym z elementów strategii odchodzenia od samochodów prywatnych jest współdzielenie samochodów, czyli korzystanie z usług takich jak samochody publiczne czy Uber. 
Stąd wsparcie dla systemów współdzielonych, również ze strony takich państw jak Korea Południowa, znaczącego producenta samochodów. Błędem jest postrzeganie rozwoju transportu zbiorowego jako kosztu - powinien być traktowany jako inwestycja, podobnie jak rozwój mobilności współdzielonej. Wydatki w tym zakresie pozwalają bowiem uniknąć znaczących kosztów bezpośrednich (np. rozbudowy sieci drogowej), jak i zewnętrznych.

\section{Samochód w gospodarce współdzielenia}

W panelu nt. przyszłości samochodu w gospodarce współdzielenia Karin Tausz z Kolei Szwajcarskich (SBB) przedstawiła jako aktualny trend bardziej spontaniczne i elastyczne zachowania podróżnych, co zwiększa wymagania wobec usług przewozowych. Rośnie przy tym konkurencja na skutek ułatwień w porównywaniu ofert przy pomocy internetu. Jednocześnie konieczna jest współpraca, również między konkurującymi podmiotami, tak by poza łańcuchami podróży zapewnić ekosystem, w którym będą one mogły być realizowane. Przydatnym dodatkowym elementem systemu mogą w takim przypadku być samochody samojezdne (zautomatyzowane), które należy zintegrować z pozostałymi elementami systemu. Rozwój systemu i współpraca powinny prowadzić do zmniejszenia liczby samochodów, mniejszego zapotrzebowania na miejsca parkingowe i większej elastyczności, przy lepszym wykorzystaniu infrastruktury drogowej i kolejowej. Wymaga to jednak zmiany podejścia już na etapie planowania. Zintegrowane podejście jest konieczne, by zapewnić możliwość utrzymania infrastruktury - zarówno liniowej, jak i punktowej (dworce itp.). Z drugiej strony, przy planowaniu rozwoju infrastruktury, należy uwzględnić przewidywane przyszłe trendy.

Ananda Grog, z holenderskiej firmy ShareNL zajmującej się sieciowaniem firm i gromadzeniem informacji nt. samochodów współdzielonych, przedstawiła wizję przyszłości, w której możliwie duża część potrzeb jest zaspokajana lokalnie za pomocą zasobów wspólnych (np. produkcja żywności), a wybory dotyczące środków transportu są wykonywane na bieżąco, na podstawie aktualnych danych. W takim systemie samochody autonomiczne są wykorzystywane przez społeczność, a gdy nie są potrzebne, załatwiają inne sprawy lub funkcjonują jako taksówki, generując dochody dla społeczności, której są własnością. Pojazdy tym samym zmieniają charakter z towaru na usługę. Gospodarka współdzielenia pozwala bardziej efektywnie wykorzystywać dostępne zasoby, np. unikając bezczynnego stania samochodów, czy ułatwiając podróże w obszarach wiejskich, gdzie wdrożenie systemów transportu publicznego jest trudniejsze.

Emily Fleck z amerykańskiego Towarzystwa Współdzielenia Samochodów (Carsharing Association) zwróciła uwagę na problemy związane z rozlewaniem się miast. Zabudowa ekstensywna znacząco utrudnia efektywny transport. Rozbudowa obszarów podmiejskich i infrastruktury drogowej w Stanach Zjednoczonych powoduje, że ponad 80\% podróży do pracy odbywa się samochodami. Przyrostowi ludności towarzyszy wieloletni trend spadku gęstości zaludnienia w obszarach istniejącej zabudowy. Skutkuje to m.in. problemami z mobilnością osób młodych, starszych i niepełnosprawnych. Nadmiar podróży samochodowych jest 
też generowany przez nadmierną podaż bezpłatnej lub niskokosztowej infrastruktury drogowej i parkingowej. Średnio na amerykańskie gospodarstwo domowe przypada 34 tys. km podróży samochodem rocznie. Aby ograniczyć skalę podróży samochodowych, rozwijane są systemy transportu zbiorowego i promowana mobilność współdzielona, konieczne jest jednak również bardziej efektywne wykorzystanie przestrzeni.

\section{Kompleksowe zarządzanie mobilnością}

Drugi dzień konferencji rozpoczął się od sesji plenarnej poruszającej kwestie mobilności współdzielonej i współpracy na poziomie miast. Guy Levin z firmy Uber podkreślił problemy wynikające z nadmiernej liczby samochodów, w tym straty czasu i zanieczyszczenie powietrza. Jednym z nowych rozwiązań wdrażanych przez Uber jest umożliwienie podróży łączonych kilku osób przemieszczających się w tym samym kierunku, tak by nie było potrzeby wykorzystywania kilku pojazdów, ani odbywania kilku podróży tym samym pojazdem.

Następnym mówcą była Karen Vancluysen, sekretarz generalny Polis - sieci europejskich miast rozwijających zintegrowane systemy transportowe, zgodne z zasadami trwałego rozwoju. Jako istotne narzędzie wspomagające całościowe planowanie działań wskazała Zintegrowane Plany Rozwoju Zrównoważonej Mobilności (SUMP). Celem polityki mobilności powinna być m.in. poprawa stanu zdrowia ludności, zarówno poprzez ograniczenie emisji, jak i ograniczenie otyłości oraz zachęcenie do aktywności ruchowej. W SUMP powinna być uwzględniona mobilność współdzielona. Przykładem efektywnego rozwiązania są rozwinięte systemy rowerów publicznych, takie jak paryski Vélib, wykorzystywany w ponad 100 tys. podróży dziennie. Innym rozwiązaniem są systemy ułatwiające wspólne podróże samochodami (carpooling). Tego typu rozwiązania zwiększają obszar, z którego można dotrzeć do transportu zbiorowego, jak też ograniczyć presję na nieefektywne wykorzystywanie przestrzeni jako miejsc parkingowych, zwalniając przestrzeń np. na tereny zielone i zadrzewienia, ograniczające zanieczyszczenie powietrza i ryzyko podtopień.

Nadal jednak należy brać pod uwagę zarówno zalety, jak i ryzyka wynikające z mobilności współdzielonej, w tym zwłaszcza jej wpływ na środowisko oraz zrównoważony rozwój społeczno-gospodarczy. Pod względem środowiskowym mobilność współdzielona może ograniczyć liczbę pojazdów, lecz może też zachęcać do podróży samochodem (zamiast np. komunikacją zbiorową). Ze społecznego punktu widzenia, tańsza oferta powinna umożliwiać podróże osobom gorzej sytuowanym, lecz jak dotąd nie są one klientami takich usług. Mobilność współdzielona ułatwia obsługę obszarów rzadko zaludnionych, jak też pozwala zwolnić przestrzeń zajętą przez parkingi, by poprawić warunki życia. Z gospodarczego punktu widzenia należy podkreślić potrzebę zintegrowania mobilności współdzielonej z transportem zbiorowym, co może wymagać poniesienia kosztów inwestycyjnych - np. na potrzeby zintegrowanego systemu biletów/opłat (choć mogą one być pokrywane $\mathrm{w}$ formule partnerstwa publiczno-prywatnego, jak też częściowo realizowane za pomocą publicznego udostępniania danych), jak też powinno być uwzględnione na etapie planowania. 
Podejmowane działania powinny wpisywać się w długofalową wizję określoną w dokumentach strategicznych i planistycznych.

Michael Lichtenegger, dyrektor wiedeńskiej spółki New Urban Mobility, zwrócił uwagę na potrzebę zmiany sposobu myślenia z „króla szos” na „dyrygenta mobilności”. W tym celu należy uwzględnić wielorakie czynniki wpływające na zachowania podróżnych - od zmiany stylu życia, przez strukturę demograficzną, ewolucję technologiczna, po zmiany na rynku i rozwijające się partnerstwa. Zmiany te - zwłaszcza w dużych miastach - widoczne są w spadającym udziale ruchu samochodowego. W przypadku Wiednia w latach 1993-2015 z 40 do 27\% przy rosnącym udziale ruchu rowerowego i komunikacji zbiorowej (celem do 2025 r. jest ograniczenie udziału ruchu samochodowego do 20\%). Komunikacja zbiorowa jest szczególnie efektywnym rozwiązaniem w dużych miastach, w których korzysta z niej co najmniej milion osób miesięcznie. Trudniejsze jest zarządzanie mobilnością w mniejszych ośrodkach (do 100 tys. mieszkańców), gdzie potrzebne jest uzupełnienie transportu zbiorowego funkcjonującego z niską częstotliwością. Również w dużych miastach wskazane jest wdrażanie rozwiązań ograniczających zapotrzebowanie na posiadanie samochodów - np. w Wiedniu już ok. 100 tys. mieszkańców korzysta z samochodów współdzielonych. Samochody współdzielone wykorzystywane są głównie na potrzeby podróży, które trudno byłoby odbyć innym środkiem transportu. Jeden zastępuje ok. 5 samochodów prywatnych.

Pojawia się przy tym pytanie o rolę zarządcy transportu zbiorowego - zapewne powinien on integrować różne dostępne opcje mobilności jako stabilny i kluczowy element systemu transportowego. Na podstawie takich założeń powstała platforma „Upstream” integrująca różne podmioty gospodarcze aktywne w dziedzinie mobilności (od kolei państwowych przez zarządców transportu miejskiego po operatorów rowerów publicznych i innych usług mobilności współdzielonej), tak by umożliwić korzystanie z ich usług i danych przez podmioty gospodarcze, jak też samych zarządców transportu, oferując zintegrowane usługi i informacje. Takie rozwiązania powinny prowadzić do zapewnienia efektywnego transportu nie tylko w centrach dużych miast, ułatwiając podróże wraz z postępem w zakresie wzrostu udziału ruchu rowerowego i pieszego oraz ograniczania wykorzystania samochodów, w tym zwłaszcza prywatnych.

Michael Roschlau, były prezes Kanadyjskiego Stowarzyszenia Transportu Miejskiego, przedstawił stan rozwoju mobilności współdzielonej w Ameryce Północnej. Podkreślił, że zintegrowana mobilność jest w coraz mniejszym stopniu kwestią rozbudowy infrastruktury i zapewniania przepustowości dla samochodów, a w coraz większym - zapewniania skutecznych usług. Oczekiwania skupiają się raczej na byciu połączonym, byciu w pobliżu i możliwości wykonywania łatwych i sprawnych podróży. Zapewnienie efektywnego systemu transportowego wymaga tym samym skupienia się na potrzebach ruchu pieszego, rowerowego i komunikacji publicznej, uzupełnionych o rozwiązania w zakresie mobilności współdzielonej. Działania w tym zakresie powinny być realizowane w myśl konkretnej wizji strategicznej i planistycznej, np. z wykorzystaniem przestrzeni przeznaczonej dotychczas dla samochodów na potrzeby aktywnych sposobów przemieszczania się. 


\section{Ograniczanie niskiej emisji, odzyskiwanie przestrzeni i wspieranie osób o ograniczonej mobilności}

W panelu nt. projektów realizowanych w ramach programu Interreg Morza Pótnocnego przedstawiano rozwiązania dotyczące wdrażania mobilności współdzielonej w celu ograniczenia emisji gazów cieplarnianych i poprawy warunków życia. Zauważono, że współdzielenie jest zasadniczą cechą infrastruktury transportowej i komunikacji zbiorowej. Nie należy przy tym rozumieć współdzielenia, jako przyznawania wszystkim dostępu na różnych zasadach - konieczne jest priorytetowe traktowanie środków transportu wydajnych i korzystnych z punktu widzenia środowiska, przestrzeni i zdrowia (szerzej - jakości życia). Skuteczność takiego podejścia widoczna jest np. w niskim stopniu zatłoczenia ulic w miastach, gdzie wysoki udział ma ruch rowerowy. Innowacje w zakresie ruchu samochodowego (np. samochody autonomiczne) niekoniecznie stanowią przy tym rozwiązanie w zakresie efektywności wykorzystania przestrzeni, stwarzając ryzyko wzrostu udziału ruchu samochodowego.

Angelo Meuleman z belgijskiej firmy Taxistop omówił możliwości lepszego wykorzystania przestrzeni ulicznej, tak by jej jedyną funkcją nie była komunikacja (w tym miejsca parkingowe), lecz również integracja i spędzanie czasu. W ramach laboratoriów ulicznych w Gandawie, po okresie próbnym - np. w postaci wyłożenia jezdni sztuczną trawą - zgodnie z wolą mieszkańców wdrażano zmiany na stałe, np. zastępując utwardzoną nawierzchnię trawnikiem. Pozwoliło to na osiągnięcie korzyści przestrzennych, społecznych i środowiskowych. Zapotrzebowanie na miejsca parkingowe zostało ograniczone m.in. poprzez samochody współdzielone i wzajemne podwożenie w środowisku sąsiedzkim.

Jeffrey Matthijs z AutoDelen.net - belgijskiej spółki udostępniającej samochody współdzielone - przedstawił sytuację w obszarach wiejskich, często pomijanych na rynku samochodów współdzielonych. Tymczasem rozwiązania w tym zakresie funkcjonują również poza miastami. Samorządy lokalne wykorzystujące samochody współdzielone udostępniają je mieszkańcom poza godzinami urzędowymi, co funkcjonuje jako usługa i przykład dla mieszkańców. Jest to rozwiązanie korzystne, jako że najwyższy popyt wśród osób prywatnych występuje w weekendy, zaś samorządy obniżają koszty funkcjonowania. W innym obszarze rzadko zaludnionym, we współpracy z organizacją pozarządową i samorządem lokalnym, rozszerzeniem oferty współdzielonych samochodów są usługi w zakresie robienia zakupów i przewozów osób o ograniczonej mobilności.

\section{Rozwój mobilności współdzielonej w Niemczech}

W ostatniej sesji przedstawiono sytuację w Niemczech. Niels Hartwig z niemieckiego ministerstwa transportu zwrócił uwagę na szybko rozwijający się rynek samochodów współdzielonych w Niemczech. Skokowy przyrost widoczny jest zwłaszcza w ciągu ostatnich kilku lat. Usługi tego typu dostępne są w ponad 500 miastach. W siedmiu z nich rynek jest na tyle rozwinięty, że dostępny jest 1 lub więcej samochodów publicznych na 1000 miesz- 
kańców. Trwają prace nad ustawą regulującą rynek samochodów współdzielonych. Rowery publiczne dostępne są w 100 miastach - w połowie z nich obsługiwane są przez Deutsche Bahn. Również w tym przypadku widoczny jest szybki przyrost popularności. Rower stał się symbolem statusu i cieszy się ogromną popularnością.

Christian Hohfeld z Agora Verkehrswende (Transformacja Transportu) zwrócił uwagę na rolę mobilności współdzielonej w dążeniu do przeciwdziałania ociepleniu klimatu. Od 1990 r. w dużej mierze udało się ograniczyć przyrost emisji gazów cieplarnianych z sektora transportowego mimo wzrostu przewozów, nie udało się jednak ograniczyć emisji w wartościach bezwzględnych. Konieczna jest zatem równoczesna zmiana zachowań transportowych, jak też zmiana źródeł zasilania środków transportu (przesunięcie z pojazdów spalinowych na elektryczne, zasilane energią pozyskiwaną ze źródeł odnawialnych). Niezbędne jest efektywne zarządzanie mobilnością, tak by motywować mieszkańców do korzystania ze skutecznych środków transportu, zwłaszcza w miastach. W przypadku samochodów współdzielonych prawdopodobnie konieczne będzie nie tylko sukcesywne, lecz równoczesne korzystanie z tych samych pojazdów (nie tylko carsharing, lecz również carpooling). Tym samym samorządy powinny przyjąć aktywną rolę kształtowania zachowań komunikacyjnych.

Michael Glotz-Richter z Urzędu Miasta Bremy zwrócił uwagę na wpływ polityki mobilności na jakość życia. Ograniczenie ruchu samochodowego poprawia warunki życia, umożliwia efektywne wykorzystanie przestrzeni, jak też może usprawnić system transportowy - poprawiając jakość życia. W przypadku Bremy istotnym elementem sukcesu jest promowanie ruchu rowerowego, jak też ograniczenie negatywnego wpływu ruchu samochodowego na warunki ruchu - wynikającego np. z przyzwolenia na parkowanie na chodnikach. Ograniczenie presji parkingowej odbywa się m.in. przez rozwój systemu samochodów współdzielonych. Równolegle powinny być poprawiane warunki ruchu pieszego. Według badań z 2015 r. klienci jednej z firm samochodów współdzielonych w 50\% posiadali własne samochody przed przystąpieniem do systemu, po czym 35\% klientów z nich zrezygnowało. Celem strategicznym do 2020 r. jest ograniczenie liczby samochodów w mieście o 6 tys. W 2013 r. zmieniono kwoty parkingowe, ograniczając obowiązek budowy miejsc parkingowych dla samochodów w nowych budynkach. Jednym z haseł promocyjnych rozwoju systemu samochodów publicznych było pytanie: „Czy gdybyś chciał napić się mleka, kupiłbyś krowę?”

\section{Podsumowanie}

Z prezentacji i dyskusji w ramach konferencji wynikają następujące wnioski:

- plany i działania dotyczące systemu transportowego powinny uwzględniać zmiany społeczno-gospodarcze i technologiczne skutkujące malejącą rolą motoryzacji indywidualnej na rzecz transportu zbiorowego i współdzielonego,

- komunikacja publiczna powinna być w możliwie największym stopniu zintegrowana z systemami transportu współdzielonego, tak by korzystanie ze środków transportu alternatywnych dla samochodów prywatnych było możliwie proste, intuicyjne i wygodne, 
- przewoźnicy publiczni mogą stwarzać i obsługiwać platformy integrujące różne podmioty działające na rynku transportowym oraz umożliwiające wymianę danych, tak by ułatwić efektywne i kompleksowe planowanie/wykonywanie podróży,

- działania podejmowane $\mathrm{w}$ odniesieniu do systemu transportowego powinny służyć osiągnięciu celów dalekosiężnych i przekrojowych (poprawa jakości życia, stanu środowiska, ograniczenie zagrożeń dla zdrowia), a nie krótkoterminowych i sektorowych (np. zwiększenie przepustowości drogi mierzonej liczbą samochodów, przyczyniające się w dłuższej perspektywie do większego zanieczyszczenia powietrza),

- prace planistyczne powinny ukierunkowywać inwestycje na zabudowę zwartą i skupioną wokół wydajnych środków transportu, tak by zminimalizować zapotrzebowanie na motoryzację indywidualna,

- w przypadku istniejącej zabudowy, przestrzeń powinna być wykorzystywana możliwie najbardziej efektywnie, tj. z preferencją dla transportu zbiorowego, współdzielonego oraz niezmotoryzowanego; w tym celu należy odzyskiwać przestrzeń przeznaczoną pod nadmiernie rozbudowaną infrastrukturę drogową (samochodową), aby poprawić jakość przestrzeni publicznej i warunki życia - tym samym tworząc warunki zachęcające do życia w mieście zamiast wyprowadzki na ekstensywnie zagospodarowane tereny podmiejskie.

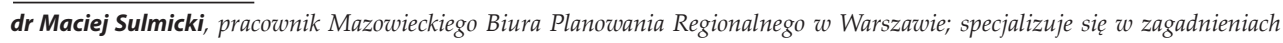
zwiazanych $z$ rozwojem regionalnym, w tym planowaniem rozwoju i transportem. 